\title{
COCONUT PRODUCTION IN SEYCHELES
}

\author{
Martin H. Fowler ${ }^{1}$
}

\section{INTRODUCTION}

This study is based on a description of the Seychelles coconut industry contained in the Central Bank quarterly Review (No. 2, 1983) and on data contained in various pubrications of the Statistics Section on the Information System Division.

\section{BACKGROUND}

The Republic of Seychelles is made up of more than 100 islands which cover a total of 453 square kilometers spread over a large area in the west of the Indian Ocean. Thirty-two of the islands are granitic, lying in a group at the centre of a continental shelf. They are characterised by a rugged and rocky topography with a naffow coastal strip and a central range of hills rising as high as 905 meters. The remainder of the islands are of coral origin, spread over a much larger area and often rising only a few metres above sea level. Most of them have no permanent population - although contract workers are taken in from time to time - and some are waterless and uninhabitable.

The equatorial climate is moderated by the ocean giving a mean maximum temperature of $30 \mathrm{C}$ and annual rainfall totals varying from 2,300 $\mathrm{mm}$ in Mahe to $500 \mathrm{~mm}$ in Aldabra. On average, 60 per cent of the rainfall occurs during the November-April north-west monsoon season. The south-west monsoon season is cooler.

The population is currently estimated to be 69,000 increasing at approximately 0.8 per cent per annum. The population is youthful with 37 per cent being under 15 years of age.

The economic structure of the country has changed radically in the past 15 years. Agriculture, particularly copra and cinnamon production, was traditionally dominant in the productive sectors in terms of its contribution to Gross Domestic Product (GDP), employment and exports. Whereas agriculture, fisheries and forestry accounted for 18.6 per cent of GDP in 1971, their contribution had fallen to 6.9 per cent by 1984 . The economy has become steadily more refiant upon services - particularly tourism and the public sector. Indeed, the importance of tourism to the economy is underlined by the fact that, by 1984, foreign exchange earnings from this sector were 12 times the earnings from merchandise exports.

\section{PRODUCTION}

Coconuts have been grown in Seychefles for many years - they were growing, for example, when the first British ships landed in 1609. By the early 1900's, copra was being exported, and by 1928 approximately 8,500 ha had been planted with coconuts. (The total surface area of the country is only 453 square kilometers, of which fittle more than 10,000 ha are suitable for agriculture). In 1962 it was estimated that a total of 2 million palms covered some 23,000 acres and produced 5,768 tonnes of copra for export. A similar acreage figure was recorded in the 1977 agricultural census.

\footnotetext{
${ }^{1}$ Agricultural Economist, African Development Bank, Abidjan.
} 
Coconuts are, grown on both the central granitic islands and on the other outer islands, with up to 75 per cent of the latters' surface area under the crop. Approximately 95 per cent of annual output comes from "large" farms, which have an average size of 125 ha.

Production reached a peak in 1964 when 7,093 tonnes were exported. But, in recent years, output has declined sharply averaging only 2,100 tonnes in the past 5 years (Table 1 ), due to several interrelated reasons:

Table 1

Exports of Coconuts and Coconut Products

\begin{tabular}{|c|r|r|r|}
\hline Year & $\begin{array}{c}\text { Coconuts } \\
\text { (Number) }\end{array}$ & $\begin{array}{c}\text { Copra } \\
\text { (in tonnes) }\end{array}$ & $\begin{array}{c}\text { Coconut Oil } \\
\text { (in tonnes) }\end{array}$ \\
\hline 1970 & n.a. & 4,490 & - \\
1971 & n.a. & 3,550 & - \\
1972 & n.a. & 3,530 & - \\
1973 & 545,900 & 3,390 & 17.3 \\
1974 & 538,250 & 3,106 & - \\
1975 & $1,156,012$ & 2,906 & - \\
1976 & 715,916 & 2,829 & 6.0 \\
1977 & $1,282,040$ & 2,965 & 3.4 \\
1978 & 187,387 & 3,000 & 1.3 \\
1979 & 242,200 & 3,439 & 1.4 \\
1980 & 614,209 & 3,200 & - \\
1981 & 291,100 & 3,136 & 6.5 \\
1982 & 321,500 & 2,176 & 10.0 \\
1983 & 148,840 & 2,686 & 96.2 \\
1984 & 249,720 & 1,766 & 81.5 \\
1985 & 289,324 & 1,632 & n.a. \\
1986 & n.a. & 2,374 & \\
\hline
\end{tabular}

Source: Republdc of Seychelles. "An Agricultural Strategy for Food

Security. FSAG Oxford, U.K. (982).

Information Systems Division. "Trade Report, 1985".

Seychelles National Printing Co. Ltd., Victoria, Seychelles (November 1986).

Statistics Division. "Production Indicator 1986".

Statistical Bulletin 1987, No. 1 (January 1987).

(a) Increasing costs of production, particularly labour, which led to fewer people being employed for maintenance activities on plantations, while coconuts in less accessible, hilly areas are no longer being harvested. Inter-island transport costs have similarly risen at a faster rate than the increase in copra prices.

(b) A reductian in the area under coconuts at the result of considerable pressure to convert agricultural land to other uses.

(c) Falling copra yields due to the ageing of the coconut stands, the lack of regular maintenance and fertilizer application (particularly in those plantations, where coconuts are interplanted 
with cinnamon), and increased pest infestation, mainly the Melittoma beetle. This beetle causes an estimated 90 per cent of the deaths of palms in Seychelles; in 1959 it was infecting more than 60 percent of the palms on Mahe, the largest island in the group. Campaigns have been carried out to improve the level of inputs on plantations.

(d) The movement of labour to more renumerative employment in the construction and tourism industries which began after 1977; Average monthly earnings in agriculture in 1982 were 30 per cent lower than those in the hotel trade. Part of the movement is also related to the low status that agriculture in general now has amongst younger generations.

As production began to fall in the late sixties, the government sought to arrest the decline through a series of measures, which included the importation and distribution at subsidised prices of fertiliser, a Melittoma pest control programme, the provision of a free soil analysis service, and the distribution of selected seedlings at subsidised prices.

The decline in production has been pronounced in the central granitic islands - particularly Mahe where the capital is located. Here, the above mentioned factors - particularly the competition from other uses for the land, and the alternative employment opportunities - are most acute. These islands now produce less than one-half of the national output compared with two-thirds a decade earlier.

\section{Export Marketing}

In 1952, the Copra Association was established in order to export copra from. Seychelles on behalf of all producers. The Association sold copra on a forward basis by means of tenders to foreign. buyers, most of whom had local representatives.

The Copra Price Stabilization Fund (CPSF) which was established in 1956, was reconstituted in 1973 and was managed thereafter by a Board. Export prices were stabilizedexporters providing contributions to the Fund when export prices exceeded a predetermined price, while the Fund compensated exporters wheii prices fell below a lower marker prices. The CPSF was responsible for revising the marker prices in the light of changes in the world market and/or local costs of production. The maximum level of compensation was $£ 15$ per tonne between 1973 and 1981, and fell to, $£ 1$ per tonne thereafter.

Between 1974 and 1980, the Fund accumulated a large surplus, amounting to R 3.68 million. This was invested by the Board subject to, the structures of an ordinance. By 1981 an R 13.9 million surplus had been accumulated and was invested within the economy.

The Seychelles National Commodity Corporation (SEYCOM) was established as the monopsonist exporter in 1981. The producere prices were thereafter fixed, according to grade, after discussions between SEYCOM and producers'representatives.

Reports indicate that the operations of SEYCOM were, initially at any rate, high-cost particularly when compared with the previous private trading operations.

\section{Exports}

The main market for Seychelles' copra in recent years has been Pakistan, which pays premiurn prices for the cup copra which forms a major part of the tonnage exported. As Table 2, shows the indices of export prices and world market prices followed one another closely until 1975 when the Seychelles price increased relative to that of the world price, and has remained relatively higher ever since (the reason for this divergence is unclear). 
Table 2

Seychelles and World Copra Export Price Indices (1970-100)

\begin{tabular}{|c|c|c|}
\hline Year & Seychelles F.O.B. & World C.I.F. \\
\hline 1970 & 100 & 100 \\
1971 & 89 & 88 \\
1972 & 59 & 65 \\
1973 & 122 & 160 \\
1974 & 283 & 307 \\
1975 & 222 & 117 \\
1976 & 276 & 126 \\
1977 & 433 & 184 \\
1978 & 477 & 216 \\
1979 & 513 & 309 \\
1980 & 470 & 208 \\
1981 & 480 & 174 \\
1982 & 360 & 144 \\
1983 & 374 & 228 \\
1984 & 411 & 326 \\
1985 & 410 & 177 \\
\hline
\end{tabular}

Source: Tables 1 and 3, and Oilworld (quoted in Cocomunity Newsletter, Vol. XVII, No. 9, Jakarta, Indonesia (May 1987).

Copra exports have, until recently, been the major source of "visible" foreign exchange earnings - during the 1970's they averaged 55 per cent of total domestic export eamings. Since reaching a peak in 1978, however, their importance has declined such that by 1985 they provided little more than one third of the total (Table 3). Fish exports are now the main source of foreign exchange eamings from visible trade while copra exports represented only 1 per cent of the value of imports in 1985.

Relatively large number of whole nuts are exported annually (Table 1), mainly to Mauritius where there is a shortage of nuts to be used in cooking. As with copra, however, the number of nuts exported is now considerably less than a decade ago - the 1985/1986 average was 229,000 compared with an average of 747,000 ten years earlier and it now represents a copra equivalent of little more than 50 tonnes.

Copra export statistics are not necessarily a good proxy for copra production in Seychelles, where tonnages exported are low relative to the carrying capacity of cargo ships. A good illustration of this is provided by data for 1986 when 2,374 tonnes were exported, compared with 1,632 tonnes in the previous year. From these data one might assurne that a significant increase in production had taken place in fact, data on copra deliveries to the export port stores show that the opposite occured - deliveries fell by 13 percent between the two years. Unfortunately, export data has to, be used as a proxy for producing since only this information and not dehveries of copra as well, was collected on a systematic basis prior to 1983 .

So far there has been little by-product processing of coconuts - traditionally coir fibre brushes and similar items have been produced, but even this industry is now contracting - exports of brushes in 1985 were worth half of their value four years earlier. 
Table 3

Contribution of Copra to Domestic Export Earnings

\begin{tabular}{|c|r|r|r|}
\hline Year & $\begin{array}{c}\text { Copra exports } \\
\text { (in SR'000) }\end{array}$ & $\begin{array}{c}\text { Domestic export } \\
\text { (in SR'000) }\end{array}$ & $\begin{array}{c}\text { Copra exports as a } \\
\text { proportion of domestic } \\
\text { exports (\%) }\end{array}$ \\
\hline 1970 & 5,079 & n.a. & - \\
1971 & 3,574 & 7,916 & 24.1 \\
1972 & 2,346 & 9,528 & 35.9 \\
1973 & 4,657 & 12,969 & 53.1 \\
1974 & 9,932 & 18,721 & 56.6 \\
1975 & 7,299 & 12,903 & 49.1 \\
1976 & 8,817 & 17,940 & 59.5 \\
1977 & 14,503 & 24,385 & 65.4 \\
1978 & 16,157 & 24,705 & 64.4 \\
1979 & 19,924 & 30,948 & 51.6 \\
1980 & 16,979 & 32,930 & 61.9 \\
1981 & 17,008 & 27,471 & 43.6 \\
1982 & 8,850 & 20,297 & 44.9 \\
1983 & 11,346 & 25,250 & 38.4 \\
1984 & 8,208 & 21,398 & 34.6 \\
1985 & 7,557 & 21,858 & \\
\hline
\end{tabular}

\section{Conclusions}

The coconut industry has been the mainstay of the Seychelles economy for much of the present century. In recent year, however due to the falling world price of copra, and the relative attractiveness of off-farm employment, it is unlikely that this trend will be reversed in the future, particularly in the light of the gloomy world market prospects for coconut products. 